\title{
PENINGKATAN DAYA TERIMA DAN KADAR PROTEIN NUGGET SUBSTITUSI IKAN LELE (CLARIAS BATRACHUS) DAN KACANG MERAH (VIGNA ANGULARIS)
}

\author{
S R Widya Areta Humaniora Justisia ${ }^{1}$, Annis Catur Adi ${ }^{2}$ \\ ${ }^{1}$ Program Studi S1 Ilmu Gizi, Fakultas Kesehatan Masyarakat, Universitas Airlangga, Surabaya \\ ${ }^{2}$ Departemen Gizi Kesehatan, Fakultas Kesehatan Masyarakat, Universitas Airlangga, Surabaya \\ Email: swara.reta@gmail.com
}

\begin{abstract}
ABSTRAK
Ikan lele dan kacang merah merupakan makanan tinggi protein dan asam amino esensial yang dapat diolah menjadi nugget sehingga dapat dijadikan alternatif snack tinggi protein. Penelitian ini bertujuan untuk mengetahui pengaruh substitusi ikan lele dan kacang merah terhadap daya terima dan kadar protein, serta menentukan komposisi terbaik untuk menghasilkan nugget yang berkualitas. Jenis penelitian dalam pengembangan formula adalah eksperimental murni dengan desain rancangan acak lengkap (RAL). Terdapat 4 (empat) jenis perlakuan (kombinasi ikan lele, tulang ikan lele, dan kacang merah) dengan 3 (tiga) kali pengulangan. Panelis yang digunakan sebanyak 35 orang panelis tidak terlatih. Analisis statistik perbedaan daya terima menggunakan uji Kruskal Wallis dan Mann Whitney pada $\alpha \leq$ 0,05. Hasil uji organoleptik menunjukkan formulasi yang paling disukai panelis adalah F1(kombinasi ikan lele dan kacang merah). Peningkatan protein per 100g nugget tertinggi adalah F1(kombinasi ikan lele dan kacang merah) yaitu 14,5 g dibandingkan dengan F0 (ikan lele) 11,5 g, terdapat perbedaan yang signifikan antara F0 dengan F1, F2, F3, F4 pada karakteristik aroma $(p=0,000)$, tekstur $(p=0,008)$, rasa $(p=0,000)$, dan bentuk $(p=0,000)$. Komposisi formula terbaik adalah F1 (kombinasi ikan lele $88 \mathrm{~g}$, kacang merah $65 \mathrm{~g}$, tepung tapioka $10 \mathrm{~g}$ ). Formula terbaik ditinjau dari komposisi terbaik, daya terima, dan kandungan gizi adalah F1 (kombinasi ikan lele dan kacang merah).
\end{abstract}

Kata kunci: daya terima, ikan lele, kacang merah, protein

\begin{abstract}
Catfish and red beans are high in protein and essential amino acid than can be processed into nuggets and used as high-protein snack alternative. This research aimed to determine the effect of catfish and red beans toward the acceptance and protein content, as well as determine the best composition to produce a good quality nuggets. Type of research in the development formula using true experimental with a completely randomized design. There were four (4) types of treatment (combination of catfish, catfish bones, and red beans) with three (3) times replication. Panelist used was 35 untrained panelists. Product acceptance was tested using statistical analysis Kruskal Wallis and Mann Whitney $(\alpha \leq 0.05)$. The result of organoleptic tests showed the most preferred nugget is F1 (combination of catfish and red beans). Highest increased protein per $100 \mathrm{~g}$ nugget is F1 (combination of catfish and red beans) with $14.5 \mathrm{~g}$ compare to F0 (catfish) with 11,5 g, there was significant difference between F0 and F1, F2, F3, F4 to the characteristic of odour $(p=0.000)$, texture $(p=0.008)$, flavor $(p=0.000)$, and form $(p=0.000)$. The best composition formula is F1 (combination of catfish and red beans). The best formula in terms of its composition, acceptability, and nutritional value was F1 (combination of catfish and red beans).
\end{abstract}

Keywords: acceptance, catfish, red beans, protein

\section{PENDAHULUAN}

Kurang energi protein (KEP) merupakan masalah gizi utama balita. Prevalensi balita gizi buruk dan gizi kurang tahun 2013 di Jawa Timur adalah $19,13 \%$ sedangkan balita kurus dan sangat kurus adalah 11,4\% (Kemenkes RI, 2013). Menurut Dinkes Provinsi Jatim (2012), penyebab utama gizi buruk adalah pola asuh (40,7\%), penyakit penyerta
(28,8\%), kemiskinan (25,1\%), dan lain-lain (5,4\%). Pola asuh serta cara pemberian makan yang kurang tepat akan berdampak pada pertumbuhan dan perkembangan anak.

Pemberian makan bayi dan anak yang benar dan sesuai dengan standar merupakan salah satu upaya mendasar untuk menjamin pencapaian kualitas tumbuh kembang anak. Menurut UNICEF, 
50\% kematian anak disebabkan oleh gizi buruk dan dua pertiga disebabkan oleh praktik pemberian makan yang kurang tepat. Oleh karena itu, upaya mengatasi masalah kekurangan gizi pada bayi dan anak balita melalui pemberian makanan tambahan menjadi hal penting dalam menyelamatkan generasi masa depan (Kemenkes RI, 2013).

Pemberian makanan tambahan (PMT) merupakan salah satu cara dalam perbaikan gizi keluarga. Salah satu upaya untuk menurunkan prevalensi gizi buruk yang dapat dilakukan adalah membuat PMT yang memiliki nilai gizi tinggi, terutama kandungan protein yang tinggi. Menurut Permenkes RI No. 66 Tahun 2014, makanan tambahan berbentuk jajanan menggunakan bahan pangan lokal yang tersedia atau dihasilkan di daerah setempat terutama bahan makanan sumber energi dan protein seperti padi-padian, umbi, kacang-kacangan, sayuran hijau, dan ikan.

Salah satu jenis hasil perikanan yang kaya akan protein dan asam amino essensial adalah ikan lele. Ikan lele mengandung asam amino lisin dan leusin yang berfungsi untuk pertumbuhan anakanak, perbaikan jaringan, menghasilkan antibodi, dan membantu penyerapan kalsium (Murniyati, dkk., 2013).

Kacang merah merupakan salah satu jenis kacang-kacangan yang mengandung protein tinggi. Kandungan arginin yang tinggi pada kacang merah mengaktifkan hormon pertumbuhan (Human Growth Hormon) yang berfungsi untuk pertumbuhan otot dan mengatur sistem imun (Fernandez, 2014). Ketersediaan ikan lele dan kacang merah mudah untuk diakses oleh masyarakat, namun dalam pengolahan masih sangat sederhana. Ikan lele hanya digoreng dan dimakan dengan sambal, sedangkan kacang merah hanya dibuat campuran es atau sup sayuran.

Inovasi dalam mengolah makanan tambahan berupa snack untuk balita adalah pembuatan nugget. Masyarakat mengenal nugget sebagai lauk, namun nugget telah mengalami pergeseran fungsi menjadi makanan jajanan atau snack. Nugget merupakan alternatif makanan cepat saji yang praktis dihidangkan karena hanya membutuhkan sedikit waktu (1-3 menit) dalam penggorengan karena nugget sudah dimasak setengah matang pada pengolahan awal.
Berdasarkan uraian diatas, penelitian ini bertujuan untuk mengetahui pengaruh substitusi ikan lele dan kacang merah terhadap daya terima dan kadar protein, serta menentukan komposisi terbaik untuk menghasilkan nugget yang berkualitas.

\section{METODE}

Penelitian pada tahap pengembangan formula adalah eksperimental murni, sedangkan pada uji organoleptik adalah eksperimental semu dengan desain rancangan acak lengkap (RAL). Terdapat 4 (empat) perlakuan dengan 3 kali pengulangan. Penelitian dilaksanakan pada bulan Februari-Mei tahun 2016. Pembuatan nugget dilakukan di Laboratorium Gizi, uji organoleptik di Posyandu Melati II Kelurahan Buring Kota Malang, dan uji kadar protein dilakukan di Laboratorium BPKI (Balai Penelitian dan Konsultasi Industri) Surabaya.

Sampel penelitian adalah nugget ikan lele dan kacang merah dengan formulasi yang telah ditentukan. Ukuran sampel yang disajikan pada panelis adalah $5 \mathrm{~g}$ untuk masing-masing formula nugget. Sampel diambil secara acak dari hasil pengulangan pada setiap perlakuan. Sampel yang dinilai adalah nugget yang disajikan dan disediakan angket uji kesukaan untuk diisi oleh panelis meliputi karakteristik warna, aroma, tekstur, rasa, dan bentuk dengan 4 skala tingkat kesukaan (1:sangat tidak suka, 2:tidak suka, 3:suka, 4:sangat suka). Panelis pada penelitian ini adalah panelis tidak terlatih yaitu ibu balita di Posyandu Melati II Kelurahan Buring Kota Malang sebanyak 35 orang. Ibu balita dipilih sebagai panelis karena ibu bertindak pengambil keputusan bagi makanan yang akan dikonsumsi oleh anak. Bahan yang digunakan dalam pembuatan nugget ikan lele dan kacang merah yaitu daging ikan lele, tulang ikan lele, kacang merah, tepung tapioka, telur, bawang putih, bawang merah, merica, garam dan gula. Sedangkan bahan tambahan sebagai pelapis adalah telur, air, tepung terigu, tepung tapioka, tepung beras, dan tepung panir.

Perbedaan komposi substitusi ikan lele dan kacang merah adalah mengganti sebagian tepung tapioka dengan kacang merah yang berfungsi 
sebagai pengikat adonan agar nugget tetap kompak dan berpengaruh pada tekstur nugget. Sedangkan penggantian sebagian ikan lele dengan kacang merah juga berfungsi sebagai alternatif sumber protein yang berpengaruh pada peningkatan kadar protein nugget. Berikut adalah formulasi nugget ikan lele dan kacang merah yang digunakan dalam penelitian:

$\mathrm{F} 0=$ Komposisi ikan lele $125 \mathrm{~g}$, tepung tapioka $38 \mathrm{~g}$

$\mathrm{F} 1=$ Komposisi ikan lele $88 \mathrm{~g}$, kacang merah $65 \mathrm{~g}$, tepung tapioka $10 \mathrm{~g}$

F2 = Komposisi ikan lele $100 \mathrm{~g}$, tulang ikan lele $25 \mathrm{~g}$, kacang merah $20 \mathrm{~g}$, tepung tapioka $18 \mathrm{~g}$

$\mathrm{F} 3=$ Komposisi ikan lele $88 \mathrm{~g}$, tulang ikan lele $25 \mathrm{~g}$, kacang merah $35 \mathrm{~g}$, tepung tapioka $15 \mathrm{~g}$

Proses pembuatan nugget terdapat 2 tahapan yaitu persiapan dan pengolahan. Pada tahap persiapan, kacang merah direndam selama 24 jam kemudian direbus selama 30 menit agar tekstur kacang merah lunak. Kacang merah ditiriskan lalu dihaluskan. Daging ikan lele dipisahkan dari kulit dan tulang lalu dihaluskan. Tulang lele yang digunakan dilunakkan menggunakan presto selama 1 jam dan dihaluskan. Selanjutnya proses pengolahan yaitu bahan ditimbang sesuai dengan ukuran formula, telur, dan bumbu ditambahkan kedalam adonan lalu diaduk rata. Adonan dicetak diatas loyang lalu dikukus selama 15 menit lalu dinginkan. Adonan pelapis dicampur dan diaduk hingga rata dan tidak ada yang menggumpal. Nugget yang telah dingin dicelupkan ke adonan pelapis lalu digulingkan ke tepung panir hingga semua permukaan tertutup tepung panir. Nugget digoreng selama 3 menit hingga berwarna kecokelatan.
Penilaian yang dilakukan pada penelitian ini adalah daya terima meliputi warna, aroma, tekstur, rasa, dan bentuk yang diperoleh dari penilaian panelis menggunakan angket uji kesukaan. Perhitungan kadar protein berdasarkan perhitungan DKBM (Daftar Komposisi bahan Makanan) dan uji laboratorium kimia. Uji Kruskal Wallis $\alpha \leq 0,05$ digunakan untuk mengetahui perbedaan pengaruh substitusi ikan lele dan kacang merah terhadap daya terima nugget dan Mann Whitney $\alpha \leq 0,05$ untuk mengetahui perbedaan tiap formula yang paling signifikan.

Penelitian ini melibatkan subjek manusia yaitu panelis untuk menilai daya terima produk. Penelitian ini telah mendapatkan persetujuan dari komisi etik penelitian kesehatan Fakultas Kesehatan Masyarakat Universitas Airlangga Surabaya.

\section{HASIL DAN PEMBAHASAN}

Hasil uji organoleptik panelis tidak terlatih terhadap tingkat kesukaan warna disajikan pada tabel 1. Tabel 1 menunjukkan tingkat kesukaan warna tertinggi adalah F1 (kombinasi ikan lele dan kacang merah) dengan mean rank (peringkat ratarata) 75,24 . Warna nugget yang dinilai oleh panelis adalah bagian dalam nugget. Hal ini dilakukan karena warna luar 4 formula nugget sama yaitu kecokelatan karena proses penggorengan, sedangkan warna bagian dalam berbeda antar formula karena pengaruh substitusi ikan lele dan kacang merah.

Berdasarkan uji organoleptik, tingkat kesukaan warna tertinggi adalah F1. Apabila dibandingkan dengan F0 yang berwarna abu-abu pucat, panelis lebih menyukai warna formula nugget lainnya ( $F 1$, F2, F3) yang berwarna lebih gelap karena adanya kacang merah dan tulang ikan lele dalam adonan.

Tabel 1. Distribusi Tingkat Kesukaan Panelis terhadap Warna Nugget

\begin{tabular}{|c|c|c|c|c|c|c|c|c|c|c|c|}
\hline \multirow{2}{*}{ Formula } & \multicolumn{2}{|c|}{1} & \multicolumn{2}{|c|}{2} & \multicolumn{2}{|c|}{3} & \multicolumn{2}{|c|}{4} & \multicolumn{2}{|c|}{ Total } & \multirow{2}{*}{ Mean Rank } \\
\hline & n & $\%$ & $\mathbf{n}$ & $\%$ & $\mathbf{n}$ & $\%$ & n & $\%$ & $\mathbf{N}$ & $\%$ & \\
\hline F0 & 4 & 11 & 10 & 29 & 12 & 34 & 9 & 26 & 35 & 100 & 62,60 \\
\hline F1 & 0 & 0 & 3 & 9 & 27 & 77 & 5 & 14 & 35 & 100 & 75,24 \\
\hline F2 & 0 & 0 & 6 & 17 & 22 & 63 & 7 & 20 & 35 & 100 & 73,69 \\
\hline F3 & 0 & 0 & 5 & 14 & 26 & 74 & 4 & 11 & 35 & 100 & 70,47 \\
\hline
\end{tabular}


Tabel 2. Distribusi Tingkat Kesukaan Panelis terhadap Aroma Nugget

\begin{tabular}{|c|c|c|c|c|c|c|c|c|c|c|c|}
\hline \multirow{2}{*}{ Formula } & \multicolumn{2}{|c|}{1} & \multicolumn{2}{|c|}{2} & \multicolumn{2}{|c|}{3} & \multicolumn{2}{|c|}{4} & \multicolumn{2}{|c|}{ Total } & \multirow{2}{*}{ Mean Rank } \\
\hline & $n$ & $\%$ & $\mathrm{n}$ & $\%$ & $\mathbf{n}$ & $\%$ & n & $\%$ & $\mathbf{N}$ & $\%$ & \\
\hline F0 & 3 & 9 & 13 & 37 & 17 & 49 & 2 & 6 & 35 & 100 & 47,81 \\
\hline F1 & 0 & 0 & 4 & 11 & 25 & 71 & 6 & 17 & 35 & 100 & 74,81 \\
\hline $\mathrm{F} 2$ & 0 & 0 & 4 & 11 & 20 & 57 & 11 & 31 & 35 & 100 & 82,96 \\
\hline F3 & 0 & 0 & 2 & 6 & 28 & 80 & 5 & 14 & 35 & 100 & 76,41 \\
\hline
\end{tabular}

Hal ini sejalan dengan pernyataan Genisa, et al. (2015) pada pembuatan bakso kacang merah di mana tingkat kesukaan warna tertinggi adalah bakso dengan penambahan kacang merah paling banyak karena berwarna lebih gelap.

Ikan lele dan kacang merah mengandung protein yang merupakan komponen reaktif dalam bahan pangan dan dapat bereaksi dengan gula pereduksi, lemak, dan produk oksidasi sehingga menyebabkan timbulnya warna yang lebih gelap dan pembentukan cita rasa (Apriyana, 2014).

Aroma merupakan sifat visual yang dapat digunakan untuk menilai kualitas dengan uji organoleptik menggunakan indera sensorik penciuman yang sensitif (Setyaningrum dan Saparinto, 2014). Aroma yang ditimbulkan nugget F0 adalah bau khas ikan lele yang lebih kuat dibandingkan dengan nugget modifikasi (F1, F2, dan F3).

Berdasarkan uji organoleptik, daya terima aroma tertinggi adalah $\mathrm{F} 3$, namun hasilnya tidak berbeda dengan $F 1(p=0,832)$ dan F2 $(p=0,320)$. Aroma khas ikan lele berkurang sehingga bau amis khas ikan lele yang tertutupi oleh kacang merah dan meningkatkan daya terima panelis. Sama halnya dengan hasil uji organoleptik aroma sosis lele pada penelitian Cahyani (2011) panelis lebih menyukai sosis ikan lele dengan penambahan kacang merah terbanyak.

Karakteristik tekstur nugget dinilai dengan cara menekan dan menggigit untuk mengetahui kekenyalan nugget. Hasil uji organoleptik tekstur nugget disajikan pada tabel 3 . Tabel 3 menunjukkan tingkat kesukaan tekstur tertinggi adalah F1 (kombinasi ikan lele dan kacang merah) dengan mean rank 84,16, sedangkan yang terendah adalah F0 (ikan lele) yaitu 42,56. Tekstur nugget adalah padat kenyal namun tidak keras, penambahan kacang merah pada formula nugget mempengaruhi tekstur nugget.

Tekstur nugget yang dinilai adalah kekenyalan. Tekstur bagian dalam nugget yang baik menurut SNI 01-6682-2002 adalah lunak kenyal dan adonan kompak. Tekstur nugget yang paling disukai panelis adalah F1. Bahan yang mempengaruhi tekstur nugget adalah proporsi tepung tapioka dan kacang merah. Pada F0 hanya digunakan tepung tapioka dan pada F1, F2, F3 tepung tapioka disubstitusi dengan kacang merah. F1 merupakan formula dengan substitusi kacang merah terbanyak dan jumlah tepung tapioka paling sedikit sehingga tekstur yang dihasilkan tidak terlalu keras tetapi tetap lunak dan kenyal sehingga cocok untuk dikonsumsi balita.

Tepung tapioka mengandung amilosa dan amilopektin yang mempengaruhi tekstur nugget yang padat dan kenyal (Simanjuntak, 2014). Sebagian tepung tapioka disubstitusi dengan kacang merah mengandung protein sebagai bahan pengisi dan pengikat yang berfungsi untuk mengikat lemak dan air dalam satu emulsi. Keunggulan kacang merah yaitu meningkatkan emulsifikasi lemak dibandingkan dengan bahan pengikat dan pengisi yang terdiri dari karbohidrat

Tabel 3. Distribusi Tingkat Kesukaan Panelis terhadap Tekstur Nugget

\begin{tabular}{|c|c|c|c|c|c|c|c|c|c|c|c|}
\hline \multirow{2}{*}{ Formula } & \multicolumn{2}{|c|}{1} & \multicolumn{2}{|c|}{2} & \multicolumn{2}{|c|}{3} & \multicolumn{2}{|c|}{4} & \multicolumn{2}{|c|}{ Total } & \multirow{2}{*}{ Mean Rank } \\
\hline & $\mathbf{n}$ & $\%$ & $\mathbf{n}$ & $\%$ & $\mathbf{n}$ & $\%$ & $\mathbf{n}$ & $\%$ & $\mathbf{N}$ & $\%$ & \\
\hline F0 & 4 & 11 & 10 & 29 & 12 & 34 & 9 & 26 & 35 & 100 & 42,56 \\
\hline $\mathrm{F} 1$ & 0 & 0 & 3 & 9 & 27 & 7 & 5 & 14 & 35 & 100 & 84,16 \\
\hline $\mathrm{F} 2$ & 0 & 0 & 6 & 17 & 22 & 63 & 7 & 20 & 35 & 100 & 80,87 \\
\hline F3 & 0 & 0 & 5 & 14 & 26 & 74 & 4 & 11 & 35 & 100 & 74,41 \\
\hline
\end{tabular}


Tabel 4. Distribusi Tingkat Kesukaan Panelis terhadap Rasa Nugget

\begin{tabular}{|c|c|c|c|c|c|c|c|c|c|c|c|}
\hline \multirow{2}{*}{ Formula } & \multicolumn{2}{|c|}{1} & \multicolumn{2}{|c|}{2} & \multicolumn{2}{|c|}{3} & \multicolumn{2}{|c|}{4} & \multicolumn{2}{|c|}{ Total } & \multirow{2}{*}{ Mean Rank } \\
\hline & $\mathbf{n}$ & $\%$ & $\mathbf{n}$ & $\%$ & $\mathbf{n}$ & $\%$ & $\mathbf{n}$ & $\%$ & $\mathbf{N}$ & $\%$ & \\
\hline F0 & 3 & 9 & 10 & 29 & 16 & 46 & 6 & 17 & 35 & 100 & 53,21 \\
\hline $\mathrm{F} 1$ & 1 & 3 & 2 & 6 & 18 & 51 & 14 & 40 & 35 & 100 & 80,96 \\
\hline $\mathrm{F} 2$ & 0 & 0 & 3 & 9 & 24 & 69 & 8 & 23 & 35 & 100 & 71,26 \\
\hline F3 & 0 & 0 & 4 & 11 & 19 & 54 & 12 & 34 & 35 & 100 & 76,57 \\
\hline
\end{tabular}

saja (Yuanita dan Silitonga, 2014). Sesuai dengan penelitian Tarigan (2016) pada nugget ikan lele dan kacang merah, sebagian besar panelis menyukai nugget dengan penambahan kacang merah paling banyak

Rasa merupakan salah satu indikator yang penting pada penilaian produk makanan. Hasil uji organoleptik rasa nugget pada tabel 4 menunjukkan tingkat kesukaan rasa tertinggi adalah F1 (kombinasi ikan lele dan kacang merah) dengan mean rank 80,96 , sedangkan yang terendah adalah F0 (ikan lele) yaitu 53,21. Rasa khas ikan lele yang gurih tidak hilang akibat penambahan kacang merah sehingga menimbulkan cita rasa baru pada nugget.

Rasa yang dinilai pada nugget adalah asin, manis, dan gurih. Berdasarkan SNI 01-6683-2002, rasa nugget yang baik adalah tidak meninggalkan rasa khas dari bahan baku pembuatan yaitu ikan lele dan kacang merah.

Berdasarkan uji organoleptik, tingkat kesukaan rasa nugget tertinggi adalah F1 yaitu nugget dengan substitusi kacang merah terbanyak. Hal ini sejalan dengan pernyataan Tarigan (2016) yaitu sebagian besar panelis menyukai rasa nugget ikan lele dan kacang merah dengan penambahan kacang merah terbanyak.

Bentuk nugget dibuat beragam yaitu persegi, bunga, orang, dan segitiga. Bentuk yang menarik dapat meningkatkan nafsu makan dan tingkat kesukaan pada suatu produk. Tabel 5 menunjukkan tingkat kesukaan bentuk yang lebih disukai adalah F3 (bunga) dengan mean rank 87,96. Pada umumnya nugget berbentuk persegi atau stick, panelis lebih menyukai nugget yang berbentuk bunga karena lebih menarik.

Penerimaan produk pangan pada umumnya melalui penilaian indra penglihatan yaitu warna dan bentuk. Bentuk yang menarik mempengaruhi nafsu makan anak agar mau mengonsumsi makanan tersebut (Febry dan Marendra, 2009).

Perbedaan perlakuan yang diberikan pada setiap formula adalah jumlah ikan lele, kacang merah, dan tepung tapioka sehingga berpengaruh pada karakteristik nugget. Hasil analisis statistik menunjukkan terdapat perbedaan yang signifikan pada penilaian aroma $(\mathrm{p}=0,000)$, tekstur $(\mathrm{p}=0,008)$, rasa $(\mathrm{p}=0,000)$, dan bentuk $(\mathrm{p}=$ $0,000)$, sedangkan pada warna tidak terdapat perbedaan yang signifikan $(p=0,440)$. Selanjutnya dilakukan uji Mann Whitney pada penilaian aroma, tekstur, rasa, dan bentuk didapatkan hasil terdapat perbedaan yang signifikan $(\alpha \leq 0,05)$ pada daya terima aroma, tekstur, rasa, dan bentuk antara F0 dengan F1, F0 dengan F2, dan F0 dengan F3, sedangkan nugget $F 1$ dengan $F 2, F 1$ dengan $F$, dan F2 dengan F3 tidak terdapat perbedaan yang signifikan.

Proporsi bahan baku yang berbeda pada tiap formula menghasilkan karakteristik nugget yang berbeda-beda, namun antara nugget modifikasi (F1, F2, F3) yang telah diberi perlakuan yaitu substitusi ikan lele dan kacang merah tidak terdapat perbedaan yang signifikan karena memiliki karakteristik yang hampir sama.

Tabel 5. Distribusi Tingkat Kesukaan Panelis terhadap Bentuk Nugget

\begin{tabular}{|c|c|c|c|c|c|c|c|c|c|c|c|}
\hline \multirow{2}{*}{ Formula } & \multicolumn{2}{|c|}{1} & \multicolumn{2}{|c|}{2} & \multicolumn{2}{|c|}{3} & \multicolumn{2}{|c|}{4} & \multicolumn{2}{|c|}{ Total } & \multirow{2}{*}{ Mean Rank } \\
\hline & $\mathbf{n}$ & $\%$ & $\mathbf{n}$ & $\%$ & $\mathbf{n}$ & $\%$ & $\mathbf{n}$ & $\%$ & $\mathbf{N}$ & $\%$ & \\
\hline F0 & 4 & 11 & 16 & 46 & 13 & 37 & 2 & 6 & 35 & 100 & 37,19 \\
\hline $\mathrm{F} 1$ & 0 & 0 & 2 & 6 & 23 & 66 & 10 & 15 & 35 & 100 & 83,11 \\
\hline $\mathrm{F} 2$ & 0 & 0 & 3 & 9 & 22 & 63 & 10 & 29 & 35 & 100 & 73,74 \\
\hline F3 & 0 & 0 & 2 & 6 & 15 & 43 & 18 & 51 & 35 & 100 & 87,96 \\
\hline
\end{tabular}


Tabel 6. Distribusi Kadar Protein per $100 \mathrm{~g}$ Nugget

\begin{tabular}{cc}
\hline Formula & Kandungan Protein $(\mathrm{g})$ \\
\hline F0 & 11,5 \\
F1 & 14,5 \\
F2 & 11,7 \\
F3 & 12,2 \\
\hline
\end{tabular}

Nugget ikan lele dan kacang merah merupakan nugget tinggi protein. Kadar protein pada $100 \mathrm{~g}$ nugget berdasarkan perhitungan DKBM (Daftar Komposisi bahan Makanan) disajikan pada tabel 6 .

Tabel 6 menunjukkan kandungan protein per 100 gram nugget terendah adalah formula F0 (ikan lele) yaitu $11,5 \mathrm{~g}$ dan tertinggi adalah formula F1 (kombinasi ikan lele dan kacang merah) yaitu 14,5 g. Hasil analisis laboratorium dilakukan pada nugget formula F1 (kombinasi ikan lele dan kacang merah) dan didapatkan nilai protein yang tidak berbeda jauh yaitu $14,13 \%$ per $100 \mathrm{~g}$ nugget.

Nugget ikan lele dan kacang merah merupakan nugget tinggi protein yang dapat dijadikan alternatif snack yang sehat. Berdasarkan hasil perhitungan DKBM, nugget dengan protein tertinggi adalah F1 (ikan lele dan kacang merah) yaitu $14,5 \mathrm{~g}$ per 100 g nugget. Hasil analisis kadar protein nugget tidak berbeda jauh dengan uji laboratorium yaitu 14,15\% per 100 g nugget. Kandungan protein yang tinggi sudah mencukupi syarat mutu nugget menurut SNI No 6683:2014 yaitu nugget minimal mengandung protein sebesar 9\% per 100g nugget.

Kandungan protein yang tinggi pada formula nugget F1 disebabkan oleh penambahan kacang merah dengan proporsi terbanyak dibandingkan formula lainnya. Peningkatan protein pada F2 dan F3 (kombinasi ikan lele, tulang ikan lele, dan kacang merah) tidak berbeda jauh dengan F0, substitusi tulang ikan lele tidak berpengaruh pada peningkatan protein karena kandungan gizi utama pada tulang ikan lele adalah mineral seperti kalsium $(6,68 \% \mathrm{~b} / \mathrm{b})$ dan fosfor $(3,78 \% \mathrm{~b} / \mathrm{b})$ (Ferazuma, et al., 2011). Kandungan protein pada $100 \mathrm{~g}$ kacang merah adalah $22,3 \mathrm{~g}$, selain itu kacang merah mempunyai susunan asam amino yang lengkap salah satu diantaranya kandungan arginin yang tinggi yaitu 56,8 mg/g protein (Astawan, 2009).

Pengolahan makanan berbasis pangan lokal seperti ikan lele dan kacang merah dapat meningkatkan nilai manfaat terutama nilai gizi bahan makanan tersebut. Kombinasi sumber protein hewani dan nabati berdampak pada peningkatan mutu protein karena asam amino pada bahan yang saling melengkapi (Tejasari, 2005). Asam amino pembatas yaitu asam amino essensial yang jumlahnya hanya sedikit pada bahan pangan. Asam amino pembatas pada kacang merah adalah metionin dan sistein di mana dapat dilengkapi dari asam amino yang terkandung pada ikan lele. Selain itu, ikan lele mengandung asam amino esensial yang dibutuhkan untuk pertumbuhan yaitu lisin dan leusin yang diperlukan untuk bayi dan anakanak (Murniyati, et al., 2013).

Protein yang terdapat pada nugget yang dikukus dan digoreng dapat mengalami denaturasi pada suhu $50^{\circ}-60^{\circ} \mathrm{C}$, denaturasi adalah proses perubahan molekul protein tanpa menyebabkan rusaknya ikatan peptida (Sumardjo, 2009). Protein yang mengalami denaturasi berdampak pada peningkatan daya cerna protein (Tejasari, 2005). Sejalan dengan Astawan (2008) yang menyatakan bahwa proses pengolahan terbaik agar protein tidak mudah rusak dan mudah diserap tubuh adalah dengan menggunakan suhu tinggi dan dalam waktu yang singkat. Hal ini sesuai dengan proses pembuatan nugget yaitu pengukusan dalam waktu singkat (15 menit) dan penggorengan (1-3 menit) sehingga protein yang terdapat pada nugget memiliki daya cerna tinggi.

\section{KESIMPULAN DAN SARAN}

Substitusi ikan lele dan kacang merah berpengaruh pada daya terima nugget. Hasil uji organoleptik nugget terhadap warna, rasa, dan tekstur yang paling disukai adalah F1 sedangkan aroma yang paling disukai adalah F2 dan bentuk yang paling disukai adalah F3. Kadar protein per 100 gram nugget tertinggi adalah F1(ikan lele dan kacang merah) yaitu 14,5 g dibandingkan F0 (ikan lele) $11,5 \mathrm{~g}$. Komposisi terbaik adalah formula nugget F1 yaitu ikan lele $88 \mathrm{~g}$, kacang merah $65 \mathrm{~g}$, dan tepung tapioka $10 \mathrm{~g}$.

Nugget kombinasi ikan lele dan kacang merah dapat dijadikan alternatif snack tinggi protein dan asam amino essensial karena memenuhi $10-15 \%$ kebutuhan sehari terutama untuk balita dengan 
mengonsumsi 1 buah nugget berukuran $20 \mathrm{~g}$ dengan kandungan energi $65 \mathrm{kkal}$ dan protein 3,7 gram yang dapat memenuhi $10-15 \%$ kebutuhan anak usia 1-3 tahun.

\section{DAFTAR PUSTAKA}

Apriyana, I. (2014). Pengaruh Penambahan Tepung Kepala Ikan Lele (Clarias sp.) dalam Pembuatan Cilok terhadap Kadar Protein dan Sifat Organoleptiknya. Jurnal Ilmu Kesehatan Masyarakat, Vol. 3(2), 1-9. Diakses dari http:// journal.unnes.ac.id/sju/index.php/ujph/article/ view/3529/3170.

Astawan, M. (2008). Nugget Ayam bukan Makanan Sampah. Diakses dari www.jawaban.com/ health.

Astawan, M. (2009). Sehat dengan Hidangan Kacang dan Biji-bijian. Jakarta: Penebar Swadaya.

Badan Standarisasi Nasional. (2002). Syarat Mutu Nugget SNI 01-6683-2002. Jakarta: BSN. Diakses dari http://bsn.go.id

Badan Standarisasi Nasional. (2014). Syarat Mutu Nugget SNI Nomor 6683:2014. Jakarta: BSN. Diakses dari http://bsn.go.id

Cahyani, K. (2011). Kajian Kacang Merah (phaseolus vulgaris) sebagai Bahan Pengikat dan Pengisi pada Sosis Ikan Lele. (Skripsi, Universitas Sebelas Maret, Surakarta). Diakses dari: eprints.uns.ac.id/10732/

Dinas Kesehatan Provinsi Jawa Timur. (2012). Waspada balita Gizi Buruk di Jawa timur. Jawa Timur: Pemantauan Status Gizi Jawa Timur.

Febri, A dan Marendra, Z. (2009). Menu Sehat dan Permainan Kreatif untuk Meningkatkan Kecerdasan Anak. Jakarta: Gagas Media.

Ferazuma, H., Marliyati, S., Amalia, L. (2011). Substitusi Tepung Kepala Ikan Lele Dumbo (Clarias Gariepinus sp) untuk meningkatkan Kandungan Kalsiun Crackers. Jurnal Gizi dan Pangan Vol 6(1), 18-27. Diakses dari journal. ipb.ac.id/
Justisia, S R. (2016). Mutu Organoleptik, Kadar Protein, dan Nilai Ekonomi Nugget Substitusi Ikan Lele (Clarias batrachus) dan Kacang Merah (Vigna angularis) sebagai Snack Batita (Unpublished thesis). Universitas Airlangga, Surabaya. (skripsi yang tidak dipublikasikan)

Kementerian Kesehatan RI. (2013). Laporan Riset Kesehatan Dasar (Riskesdas) 2013. Jakarta; Badan Penelitian dan Pengembangan Kesehatan Kementerian Kesehatan RI.

Kementerian Kesehatan RI. (2013). Pelatihan Pemberian Makan Bayi dan Anak (PMBA). Diakses dari http://gizi.depkes.go.id/pelatihanpemberian-makan-bayi-dan-anak-pmba

Murniyati., Suryaningrum, T., Muljanah, I. (2013). Membuat Filet Lele dan Produk Olahannya. Jakarta: Penebar Swadaya.

Permenkes RI Nomor 66 Tahun 2014 Tentang Pemantauan Pertumbuhan, Perkembangan, dan Gangguan Tumbuh Kembang Anak. Jakarta.

Setyaningrum, H dan Saparinto, C. (2014). Panduan Lengkap Gaharu. Jakarta: Penebar Swadaya.

Simanjuntak, T. (2014). Komponen Gizi dan Pengaruh Pangan ala Papua. Yogyakarta: Deepublish.

Sumardjo, D. (2009). Pengantar Kimia: Buku Panduan Kuliah Mahasiswa Kedokteran dan Program Strata 1 Fakultas Bioeksakta. Jakarta: EGC.

Tarigan, J. (2016). Daya Terima Nugget Ikan Lele yang Memanfaatkan Tepung Kacang Merah dan Kandungan Gizinya. (Skripsi, Universitas Sumatra Utara, Sumatra). Diakses dari: repository. usu.ac.id/bitstream/123456789/58692/

Tejasari. (2005). Nilai Gizi Pangan. Yogyakarta : Graha Ilmu.

Yuanita dan Silitonga. (2014). Sifat Kimia dan Palatabilitas Nugget Ayam Menggunakan Jenis dan Konsentrasi Bahan Pengisi yang Berbeda. Jurnal Ilmu Hewani Tropika, Vol 11(1), 1-5. diakses dari:jurnal.unpad.ac.id/index.php/ jurnalilmuternak/article/download/393/491 